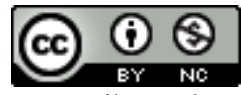

Jurnal Pendidikan Matematika Indonesia is licensed under

A Creative Commons Attribution-Non Commercial 4.0 International License.

\title{
PENINGKATAN KEMAMPUAN BERPIKIR KRITIS MATEMATIS SISWA MELALUI PEMBELAJARAN RECIPROCAL TEACHING
}

\author{
Khoerul Umam \\ 1) Universitas Muhammadiyah Prof. DR. HAMKA, Jakarta,, Indonesia \\ E-mail: khoerul.umam@uhamka.ac.id
}

\begin{abstract}
Abstrak: Kemampuan berpikir kritis matematis siswa berperan penting dalam pembelajaran matematika. Penelitian ini bertujuan untuk meningkatkan kemampuan berpikir kritis matematis siswa dengan menggunakan model pembelajaran reciprocal teaching. Metode penelitian yang digunakan adalah metode quasi-eksperimen. Sampel penelitian berjumlah 36 orang untuk kelas eksperimen dan 36 orang untuk kelas kontrol. Instrumen penelitian menggunakan tes essay yang telah didesain untuk mengukur kemampuan berpikir kritis matematis siswa. Hasil penelitian menunjukkan bahwa (1) terdapat peningkatan kemampuan berpikir matematis siswa yang diajarkan dengan menggunakan reciprocal teaching dan (2) hasil penelitian menunjukkan bahwa thitung 4,73 > tabel 1,67 dapat diinterpretasi bahwa Model Pembelajaran Reciprocal Teaching memiliki pengaruh terhadap peningkatan Kemampuan Berpikir Kritis Matematis Siswa.
\end{abstract}

Kata Kunci : Reciprocal Teaching, Kemampuan Berpikir Kritis Matematis.

\section{INTRODUCTION}

Umam (2016) menjelaskan bahwa pembelajaran matematika saat ini tidak hanya berorentasi pada hasil belajar matematika. Rizky, Ariyanto,\& Sutrisno (2017) menambahkan bahwa pembelajaran matematika perlu mengarahkan siswa untuk mengembangkan kemampuan berpikir kritis. Pengembangan kemampuan berpikir kritis harus berorentasi pada persepsi yang benar dan rasional, analisis asumsi dan bias argument, dan interprestasi logis (Kowiyah, 2012; Umam et al, 2017). Pengembangan berpikir kritis dalam pembelajaran matematika akan meningkatkan seseorang dalam menggunakan kemampuan otaknya untuk berpikir secara logis, terstruktur dan tepat dalam memecahkan suatu masalah matematika.

Berpikir kritis dalam pembelajaran bertujuan untuk mengarahkan siswa untuk memiliki cara berpikir yang terstruktur dan cerdas dalam mengorganisasikan antar konsep untuk memecahkan masalah. Data studi pendahuluan menunjukkan bahwa tidak sedikit siswa yang kurang terampil memecahkan masalah dan menemukan alternatif-alternatif pemecahan yang bervariasi. Penelitian Hendryawan, Yusuf, Wachyar, Siregar, \& Dwiyanti (2017) memperkuat bahwa kurangnya implementasi berpikir kritis dalam pembelajaran matematika telah menyebabkan rendahnya kemampuan berpikir kritis siswa. Dalam meningkatkan kemampuan berpikir kritis matematis siswa, diperlukan suatu upaya dalam memperbaiki proses pembelajaran matematika. Perbaikan pembelajaran dengan mengedepankankan pendekatan konstruktivis(Umam, 2011).

Purwoko, Pudjobroto, \& Setyaningsih menjelaskan bahwa reciprocal teaching merupakan suatu model pembelajaran dengan pendekatan konstruktivis yang berdasarkan pada prinsip-prinsip pengajuan pertanyaan, dimana keterampilan-keterampilan metakognitif akan ditingkatkan. Pembelajaran matematika dengan reciprocal teaching memberikan kesempatan siswa untuk meningkatkan berbagai keterampilan kognitif dengan menciptakan pengalaman belajar yang menyenangkan (Gowa, 2015). 
Pembelajaran matematika dengan reciprocal teaching berorentasi pada aktivitas sehingga peran guru sebagai fasilitator akan memberikan semangat, dukungan melalui scaffolding yang terstruktur (Trianto, 2010). Schukajlow, Kolter, \& Blum (2015) menjelaskan bahwa scaffolding yang terstruktu dapat memfasilitasi siswa untuk meningkatkan kemampuan berpikir kritis matematis siswa.

\section{KAJIAN TEORI}

\section{Kemampuan Berpikir Kritis}

Nisak \& Hadi, (2015) menjelaskan bahwa berpikir kritis adalah kemampuan berpikir dengan memberi alasan secara terorganisasi dan mengevaluasi kualitas suatu alasan secara sistematis serta memutuskan keyakinan. Berpikir kritis mempertimbangkan dan mengevaluasi informasi yang pada akhirnya memungkinkan siswa secara aktif membuat keputusan (Rizky et al., 2017, Umam \& Kowiyah, 2018). Berpikir kritis dapat dikatakan sebagai bentuk kegiatan mental atau pikiran manusia yang aktif. Berpikir kritis dalam matematika adalah berpikir yang menguji, mempertanyakan, menghubungkan, dan mengevaluasi semua aspek yang ada dalam situasi apapun dalam suatu masalah (Fachrurazi, 2011). Indikator-indikator berpikir kritis matematis dalam pembelajaran reciprocal teaching ini mengacu pada (Ennis, 1996) yaitu sebagai berikut :

1) Test Thinking (menguji) yaitu memberikan hasil yang tepat dan sesuai dengan prosedur, menemukan ide-ide dalam memecahkan masalah.

2) Questioning (mempertanyakan) yaitu menemukan akar permasalahan dengan tepat, menjelaskan suatu permasalahan dengan menghadirkan argumen yang ada.

3) Connecting (menghubungkan) yaitu menjelaskan perbedaan/persamaan suatu masalah, menghubungkan dua objek yang memiliki beberapa sifat yang sama.

4) Evaluation (mengevaluasi) yaitu mempertimbangkan hasil nilai dan menentukan kesimpulan dari solusi permasalahan yang telah diperoleh.

\section{Model Pembelajaran Reciprocal Teaching}

Reciprocal teaching merupakan suatu pendekatan terhadap pengajaran siswfPura akan strategi-strategi belajar (Gowa, 2015). Pembelajaran reciprocal teaching mengharuskan siswa untuk berperan aktif dalam proses pembalajaran matematika di kelas. Hasanah, Rochmad, \& Hidayah (2012) menjelaskan bahwa model pembelajaran reciprocal teaching adalah suatu model pembelajaran yang membiasakan siswa menggunakan empat strategi pemahaman mandiri, yaitu : (a) Menyimpulkan bahan ajar (summarizing), (b) Menyusun pertanyaan dan menyelesaikannya (questioning), (c) Menjelaskan kembali pengetahuan yang sudah didapat (clarifying), dan (d) Memprediksi (predicting). Pembelajaran reciprocal teaching adalah strategi belajar melalui kegiatan mengajarkan teman (Palu, Khaeri, \& Hamid, 2015). Pada strategi ini siswa berperan sebagai "guru" menggantikan peran guru untuk mengajarkan temantemannya. Pembelajaran terbalik terutama dikembangakan untuk membantu guru menggunakan dialog-dialog belajar bersifat kerjasama untuk mengajarkan pemahamanpemahaman bacaan secara mandiri di kelas.

\section{METODE PENELITIAN}

Metode penelitian yang digunakan adalah metode quasi experimental design. Pada quasi experimental, subyek tidak diambil secara acak melainkan peneliti menerima subyek yang telah ada. Penggunaan quasi experimental ini didasarkan atas pertimbangan bahwa kelas yang ada sebelumnya terbentuk sehingga tidak dilakukan pengelompokkan individu secara acak yang akan mengganggu jalannya Kegiatan Belajar Mengajar (KBM) di sekolah.

Penelitian ini dilakukan pada dua kelas yang masingmasing mempunyai karakteristik yang sama. Kelas eksperimen, yaitu kelas yang diajar dengan menggunakan model pembelajaran reciprocal teaching dan kelas kontrol, 


\section{A - - - Jurnal Pendidikan Matematika Indonesia \\ Volum 3 Nomor 2 bulan September 2018 Page 57 - 61 \\ p-ISSN: 2477-5967 e-ISSN: 2477-8443}

yaitu kelas yang diajar dengan menggunakan pembelajaran konvensional. Desain penelitian yang digunakan adalah static grup comparison.

Populasi adalah wilayah generalisasi yang terdiri atas: objek/subjek yang mempunyai kualitas dan karakteristik tertentu yang ditetapkan oleh peneliti untuk dipelajari dan kemudian ditarik kesimpulannya (Sugiyono, 2012; Umam, Purwanto, \&Aprilina, 2016). Sampel terdaftar pada semester genap tahun pelajaran 2014/2015.

Teknik pengambilan sampel yang dilakukan dalam penelitian ini menggunakan teknik Cluster Sampling yaitu pengambilan sampel didasarkan atas tujuan tertentu (Arikunto, S., 2006). Kedua kelas yang digunakan untuk penelitian kemudian diundi sehingga didapat kelas eksperimen yaitu kelas VII-B sebayak 36 siswa, dan kelas kontrol yaitu VII-A sebanyak 36 siswa.

\section{IV.HASIL DAN PEMBAHASAN}

\section{Uji Normalitas Kelas Eksperimen dan Kelas Kontrol}

Data perhitungan mengenai uji normalitas kelompok eksperimen dan kelompok kontrol dapat dilihat pada tabel I di bawah ini:

TABEL I

Uji Normalitas Kelas Eksperimen dan Kontrol

\begin{tabular}{ccccc}
\hline Variabel & $\begin{array}{c}\text { Jumlah } \\
\text { sampel }\end{array}$ & Mean & $\mathbf{L}_{\text {hitung }}$ & $\mathbf{L}_{\text {tabel }}$ \\
\hline Eksperimen & 36 & 70,28 & 0,139 & 0,148 \\
Kontrol & 36 & 58,33 & 0,134 & 0,148
\end{tabular}

Berdasarkan perhitungan uji normalitas data didapat $\mathrm{L}_{\text {hitung }}$ kelompok eksperimen sebesar 0,139 dan pada tabel harga kritis $\mathrm{L}_{\text {tabel }}$ untuk $\mathrm{n}=36$ pada taraf signifikan $\alpha=0,05$ adalah 0,148 karena $\mathrm{L}_{\text {hitung }}<\mathrm{L}_{\text {tabel }}$, maka pada kelompok eksperimen berdistribusi normal. Sedangkan pada kelompok kontrol didapat $\mathrm{L}_{\text {hitung }}$ sebesar 0,134 dan pada tabel harga kritis $\mathrm{L}_{\text {tabel }}$ untuk $\mathrm{n}=36$ pada taraf signifikan $\alpha=0,05$ adalah 0,148 . karena $\mathrm{L}_{\text {hitung }}<\mathrm{L}_{\text {tabel}}$, maka pada kelompok kontrol berdistribusi normal. Jadi, dapat disimpulkan bahwa kedua kelas tersebut berdistribusi normal.

\section{Uji Homogenitas Kelas Eksperimen dan Kelas Kontrol}

Data uji homogenitas kelas eksperimen dan kelas kontrol dapat dilihat pada tabel II sebagai berikut;

TABEL II

Uji Homogenitas Kelas Eksperimen dan Kontrol

\begin{tabular}{ccc}
\hline Variabel & Varians $\left(\mathbf{s}^{\mathbf{2}}\right)$ & Uji Fisher \\
\hline Eksperimen & 18,67 & $(0,57<1,03<1,76)$ \\
Kontrol & 18 & $\mathrm{H}_{\mathrm{o}}$ diterima \\
\hline
\end{tabular}

Hasil perhitungan skala berpikir kritis siswa diperoleh nilai varians kelas eksperimen sebesar 18,67 dan varians kelas kontrol sebesar 18 sehingga didapat $F_{\text {hitung }}=1,03$. Kriteria pengujian homogenitas adalah jika dengan taraf signifikan

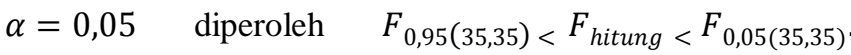
Diperoleh $\mathrm{F}_{0,05(35,35)}=1,76$ dan $\mathrm{F}_{0,95(35,35)}=0,57$, maka kesimpulannya adalah perhitungan uji homogenitas dengan menggunakan Uji Fisher didapatkan $F_{\text {hitung }}=1,03$ terletak antara 0,57 dan $1,76(0,57<1,03<1,76) . H_{0}$ diterima sehingga dapat disimpulkan bahwa dari data kedua kelas yaitu kelas eksperimen dan kelas kontrol mempunyai varians yang sama. Dengan demikian, kedua kelas adalah homogen.

\section{Effect Size (ES)}

Untuk mengetahui besarnya pengaruh dengan manggunakan rumus Effect Size, diperoleh sebagai berikut :

$$
E S=\frac{\overline{Y_{E}}-\bar{Y}_{C}}{S_{C}}=\frac{20,11-15,33}{4,24}=\frac{4,78}{4,24}=1,12
$$

Diperoleh ES sebesar 1,12 dan berdasarkan kriteria pengujian termasuk dalam kriteria tinggi. Setelah didapat bahwa kedua kelompok tersebut berdistribusi normal dan homogen, selanjutnya dilakukan pengujian hipotesis menggunakan uji-t dengan $\alpha=0,05$ yaitu menguji $\mathrm{H}_{\mathrm{o}}$ yang menyatakan bahwa kemampuan berpikir kritis siswa terhadap pelajaran matematika yang menggunakan pengajaran terbalik (reciprocal teaching) sama dengan kemampuan berpikir kritis siswa yang menggunakan pembelajaran konvensional.

Dari hasil analisis data menggunakan statistik uji-t diperoleh harga $t_{\text {hitung }}=4,73$. Dari tabel distribusi t untuk taraf signifikan $\alpha=0,05 \mathrm{dan} \mathrm{dk}=1,67$. Hasil perhitungan uji hipotesis disajikan pada tabel III berikut : 


\section{- - - Jurnal Pendidikan Matematika Indonesia \\ Volum 3 Nomor 2 bulan September 2018 Page 57 - 61 \\ p-ISSN: 2477-5967 e-ISSN: 2477-8443}

TABEL III

Data Uji Perbedaan Data Kelas Eksperimen dan Kontrol

\begin{tabular}{cccccc}
\hline \multicolumn{1}{c}{ Kelas } & Mean & Varians & $\mathbf{S}_{\text {gab }}$ & $\mathbf{t}_{\text {hitung }}$ & $\mathbf{t}_{\text {tabel }}$ \\
\hline Eksperimen & 70,28 & 18,67 & 4,28 & 4,732 & 1,669 \\
Kontrol & 58,33 & 18 & & & \\
\hline
\end{tabular}

Dari tabel III di atas diperoleh perhitungan bahwa $\quad t_{\text {hitung }}$ $>t_{\text {tabel. }}$. Menurut kriteria pengujian hipotesis, $\mathrm{H}_{\mathrm{o}}$ diterima jika $t_{\text {hitung }}$ lebih kecil atau sama dengan $\mathrm{t}_{\text {tabel }}$. Ternyata didapat $\mathrm{t}_{\text {hitung }}$ sebesar 4,73 berarti lebih besar dari $t_{\text {tabel }}$ yaitu 1,67 sehingga dapat disimpulkan bahwa hipotesis nol ditolak dan hipotesis alternative diterima dengan taraf signifikan $5 \%$, jadi jelas bahwa $t_{\text {hitung }}$ jatuh pada daerah penolakan $\mathrm{H}_{\mathrm{o}}$ (daerah kritis). Hal ini berarti terdapat perbedaan yang signifikan antara kemampuan berpikir kritis siswa yang diberi perlakuan dengan pembelajaran reciprocal teaching dan yang tidak diberikan perlakuan dengan pembelajaran reciprocal teaching.

Berdasarkan hasil penelitian yang diperoleh, terlihat adanya perbedaan rata-rata nilai kemampuan berpikir kritis matematis siswa pada kelas eksperimen dan kelas kontrol. Rata-rata berpikir kritis siswa kelompok eksperimen didapat sebesar 70,28 dan rata-rata berpikir kritis siswa pada kelompok kontrol sebesar 58,33 dan setelah dilakukan perhitungan hipotesis dengan menggunakan uji-t pada taraf signifikan $\alpha=0,05$ diperoleh $t_{\text {hitung }}>$ dari $t_{\text {tabel }}$ atau 4,73> 1,67 yang berarti terdapat perbedaan yang signifikan antara siswa yang diberi perlakuan pembelajaran reciprocal teaching dengan siswa yang tidak diberikan perlakuan dengan reciprocal teaching terhadap kemampuan berpikir kritis siswa. Hasil penelitian ini memperkuat bahwa penelitian Awaliah \& Idris (2015) yang menunjukkan bahwa reciprocal teaching berpengaruh positif dalam meningkatkan hasil belajar matematiswa siswa kelas VIII. Penelitian Hasanah et al., (2012) menunjukkan bahwa reciprocal teaching dapat meningkatkan kemampuan komunikasi matematis siswa. Hal ini dapat disimpulkan bahwa terdapat pengaruh model pembelajaran reciprocal teaching terhadap kemampuan berpikir kritis matematis siswa.

\section{SIMPULAN}

Kemampuan berpikir kritis matematis siswa dapat ditingkatkan dengan menggunakan pembelajaran reciprocal teaching. Perbedaan nilai tes akhir (posttest), antara kelas eksperimen dan kelas kontrol menunjukkan bahwa perbedaan perlakuan yang diberikan sangat berpengaruh dalam proses pembelajaran. Pada perlakuan menggunakan model reciprocal teaching, tingkat kemampuan berpikir kritisnya lebih tinggi.

\section{UCAPAN TERIMA KASIH}

Kami ingin mengucapkan terima kasih kepada Universitas Muhammadiyah Prof. DR. HAMKA dan LPDP (Lembaga Pengolola Dana Pendidikan) Departemen Keuangan, Indonesia untuk mendukung penelitian ini. Kami berharap tulisan ini dapat memberikan kontribusi yang besar terutama untuk pendidikan matematika.

\section{DAFTAR PUSTAKA}

Arikunto, S. (2006). Dasar-Dasar Evaluasi Pendidikan. Jakarta : PT. Bumi Aksara.

Awaliah, R., \& Idris, R. (2015). Pengaruh Penggunaan Model Reciprocal Teaching terhadap Hasil Belajar Matematika Siswa Kelas VIII MTsN Balang- balang Kecamatan Bontomarannu Kabupaten Gowa. Jurnal Matematika Dan Pembelajaran, 3(1), 59-72.

Ennis, R. H. (1996). Critical Thinking Dispositions: Their Nature and Assessability. Informal Logic, 18(1996), 165-182.

Fachrurazi. (2011). Penerapan Pembelajaran Berbasis Masalah Untuk Meningkatkan Kemampuan Berpikir Kritis Dan Komunikasi Matematis Siswa Sekolah Dasar. Jurnal Penelitian Pendidikan UPI, (1), 76-89. https://doi.org/10.1017/CBO9781107415324.004

Gowa, K. (2015). Pengaruh penggunaan model reciprocal teaching terhadap hasil belajar matematika siswa kelas viii mtsn balang-balang kecamatan bontomarannu kabupaten gowa. MaPan : Jurnal Matematika Dan Pembelajaran, 3(1), 59-72.

Hasanah, S., Rochmad, \& I.Hidayah. (2012). Pembelajaran model reciprocal teaching bernuansa pendidikan karakter untuk meningkatkan kemampuan komuniasi matematis. Unnes Journal of Mathematics Education Research, 1(2), 134-138.

Hendryawan, S., Yusuf, Y., Wachyar, T. Y., Siregar, I., \& Dwiyanti, W. (2017). Analisis Kemampuan Berfikir Kritis Matematis 
Siswa Smp Tingkat Rendah Pada Pembelajaran Berbasis Masalah Dengan Green's Motivational Strategies. Aksioma, $8(2), 50-58$.

Kowiyah. (2012). Kemampuan Berpikir Kritis. Jurnal Pendidikan Dasar, 3(5), 175-179.

Nisak, S. K., \& Hadi, S. (2015). Analisis proses berpikir kritis siswa dalam menyelesaikan soal peluang. In Prosiding (pp. 208219).

Palu, S. M. P. N., Khaeri, F., \& Hamid, A. (2015). Penerapan Model Pembelajaran Reciprocal Teaching Untuk Meningkatkan Hasil Belajar Siswa Pada Materi Luas Permukaan Dan Volume Kubus Dan Balok Di Kelas VIII. Jurnal Elektronik Pendidikan Matematika Tadulako, 02(03), 261-272.

Purwoko, Y. D., Pudjobroto, A. H., \& Setyaningsih, E. (2013). THE USE OF RECIPROCAL TEACHING TO IMPROVE STUDENTS' READING COMPREHENSION SKILL. English Education, 2(3), 394-401.

Rizky, I. De, Ariyanto, L., \& Sutrisno. (2017). Meningkatkan Kemampuan Berpikir Kritis Matematis Siswa Kelas. In Prosiding - SEMINAR NASIONAL MATEMATIKA DAN PENDIDIKAN MATEMATIKA (2nd SENATIK) (pp. 139145).

Schukajlow, S., Kolter, J., \& Blum, W. (2015). Scaffolding mathematical modelling with a solution plan. ZDM Mathematics Education, 47(7), 1241-1254. https://doi.org/10.1007/s11858-015-0707-2
Umam, K. (2011). Perbedaan Hasil Belajar Matematika dengan metode problem posing dan metode ekspositori. Paper disajikan dalam Prosiding Seminar Nasional Matematika dan Pendidikan Matematika UNESA (pp 339-345).

Umam, K. (2016). Pengaruh Menggunakan Software Macromedia Flash 8 Terhadap Hasil Belajar Matematika Siswa Kelas VIII. KALAMATIKA Jurnal Pendidikan Matematika, 1(1), 84-92.

Umam, K., Purwanto, S. Edy., Aprilina, C. N (2016). Penggunaan Model Problem Based Learning Dengan Bantuan Software Geogebra Untuk Meningkatkan Hasil Belajar Matematika Siswa. Paper disajikan dalam Konferensi Nasional Pendidikan Matematika-VI Universitas Negeri Gorontalo, Gorontalo, Indonesia (pp 187-199).

Umam, K., Suswandari, N. A., Wibowo, I. T., \& Rohim, S. (2017) The Effect of Think-Pair-Share Cooperative Learning Model Assisted With ICT on Mathematical Problem Solving Ability among Junior High School Students. Paper disajikan dalam Proceedings of the 26rd International Conference on Computers in Education (ICCE 2018), Christchurch, New Zealand ( $p$ p 94-98)

Umam, K., \& Kowiyah, K. (2018). The Effect of Non-Routine Geometry Problem on Elementary Students Belief in Mathematics: A Case Study. JETL (Journal Of Education, Teaching and Learning), 3(1), 99-103. 